\title{
Pengaruh Ekstrak Pegagan (Centella Asiatica (L.) Terhadap Profil Darah dan Hepar Pada Tikus Putih yang Diinduksi Asap Rokok
}

Yudha Anggit Jiwantoro, Miftahul Jannah

\begin{abstract}
Abstrak
Pegagan mengandung beberapa komponen beraktivitas biologis yang sangat bermanfaat salah satunya berkasiat sebagai hepatoprotektor yaitu melindungi sel hati dari berbagai kerusakan akibat racun dan zat berbahaya seperti asap rokok. Tujuan: Menganalisis pengaruh ekstrak Pegagan (Centella Asiatica) terhadap profil darah dan hepar pada tikus yang diinduksi asap rokok. Metode: Penelitian ini adalah true eksperiment dengan desain post test only control group design. Jumlah sampel sebanyak 5 ekor tiap kelompok dengan 5 perlakuan sehingga total sampel 25 ekor tikus. Analisa data menggunakan uji normalitas, uji homogenitas, One way ANOVA, dan post hoct test. Hasil: Pemberian ekstrak pegagan dengan dosis terapi sebesar $250 \mathrm{mg} / \mathrm{kgbb}, 500 \mathrm{mg} / \mathrm{kgbb}$, dan $1000 \mathrm{mg} / \mathrm{kgbb}$ terhadap tikus putih yang diinduksi asap rokok selama 7 minggu tidak menunjukkan perbedaan profil darah secara keseluruhan, hanya nilai limfosit dan trombosit yang menunjukkan hasil signifikan $(p<0,05)$. Pemberian ekstrak pegagan pada profil hepar (SGPT \& SGOT) tidak menunjukkan pengaruh yang signifikan $(p>0,05)$. Simpulan: Ekstrak pegagan berpengaruh terhadap profil darah (limfosit dan trombosit).
\end{abstract}

Kata kunci: asap rokok, ekstrak pegagan, profil darah, profil hepar

\section{Abstract}

Gotu kola contains several biological activity components that are very useful, one of which is efficacious as a hepatoprotection, which is to protect liver cells from various damage caused by poisons and harmful substances. Objectives: To analyzed the effect of Centella asiatica extract on centipede and blood profile in cigarette smokeinduced white rats. Methods: This was a true experiment with post-test only control group design. The number of samples were 5 per group with 5 treatments so that the total samples were 25 rats. Data analysis used the normality test, homogeneity test, One way ANOVA, and post hoct test. Results: Gotu kola extract with a therapeutic dose of 250 $\mathrm{mg} / \mathrm{kg}, 500 \mathrm{mg} / \mathrm{kg}$, and $1000 \mathrm{mg} / \mathrm{kg}$ for white rats induced by cigarette smoke for 7 weeks did not show differences in overall blood profile, only lymphocyte and platelet values showed significant results in ( $p$-value <0.05). The administration of gotu kola extract in the liver profile (SGPT \& SGOT) did not show a significant effect ( $p$ value>0.05).

Conclusion: The gotu kola extract influenced the blood profile (lymphocytes and platelets).

Keywords: cigarette smoke, gotu kola extract, blood profile, liver profile

Affiliasi penulis: Jurusan Analis Kesehatan, Politeknik Kesehatan Kementerian Kesehatan Mataram, Indonesia

Korespondensi: Jurusan Analis Kesehatan, Poltekkes Kemenkes Mataram, Email : d3d4tIm@gmail.com Telp: (0370) 622143

\section{PENDAHULUAN}

Rokok mengandung berbagai macam bahan kimia, yang terdapat dalam tembakau yang dibakar yaitu mengandung 4000 jenis bahan kimia dan 200 jenis diantaranya bersifat racun. ${ }^{1}$ Tiga komponen toksik utama yang terdapat dalam rokok adalah karbonmonoksida, tar dan nikotin. Karbonmonoksida dalam asap rokok ditemukan sebanyak lima kali lipat pada asap samping daripada pada asap utama. Karbonmonoksida bertahan selama beberapa jam di dalam ruangan setelah perokok berhenti merokok. ${ }^{2}$ Asap rokok juga terdiri dari berbagai oksidan dan radikal bebas yang bisa merusak lipid, protein, Deoxyribo Nucleic Acid (DNA), karbohidrat serta berbagai biomolekul lainnya. ${ }^{3}$ 
Merokok merupakan salah satu faktor resiko dari berbagai penyakit jantung, hipertensi, inflamasi, stroke, kelainan pembekuan darah, dan juga penyakit pernafasan. Merokok juga mempercepat patogenesis dari berbagai penyakit keganasan, misalnya keganasan paru, pankreas, payudara, hati, dan ginjal. ${ }^{4}$ Dalam penelitian beberapa tahun terakhir, dikemukakan bahwa merokok juga dapat memengaruhi komponen darah, misalnya pengaruh rokok pada jumlah sel darah putih (leukosit) yang menunjukkan bahwa terdapat peningkatan sel darah putih pada perokok dari pada bukan perokok. ${ }^{5}$

Perokok aktif maupun pasif juga diketahui memiliki pengaruh terhadap trombosit. Seseorang yang sudah lama terpapar asap rokok mempunyai potensi terjadi peningkatan agregasi trombosit dan ekskresi metabolit tromboksan. ${ }^{6}$ Pada penelitian Butkiewicz et al tahun 2006 didapatkan peningkatan jumlah trombosit pada perokok dibandingkan dengan yang tidak merokok, meskipun secara statistik hasilnya tidak bermakna. ${ }^{6}$

Darah merupakan komponen yang sangat penting karena berfungsi untuk mengedarkan substansi yang masuk ke dalam tubuh maupun yang dihasilkan tubuh dari proses metabolism, oleh karena itu darah menjadi salah satu parameter pokok dalam penelitian praklinik/biomedik. Hematologi adalah ilmu yang mempelajari cara penilaian darah. Nilai hematologi (profil darah) berguna untuk menilai kondisi kesehatan dan sebagai acuan nilai awal (baseline) atau kontrol dalam suatu penelitian. Adanya gangguan metabolisme, penyakit, kerusakan struktur dan/atau fungsi organ, pengaruh agen/obat, dan stres dapat diketahui dari perubahan profil darah. ${ }^{7}$

Pegagan (Centella Asiatica (L.), telah lama dimanfaatkan sebagai obat tradisional baik dalam bentuk bahan segar, kering maupun dalam bentuk ramuan. Tanaman ini telah terbukti memiliki efek farmakologi yang telah terbukti dari beberapa penelitian, di Australia pegagan telah banyak dimanfaatkan sebagai obat untuk penyembuhan luka, radang, rematik, asma, wasir, tuberculosis, diserti, demam dan penambahan selera makan. ${ }^{8}$

Pegagan mengandung beberapa komponen beraktivitas biologis yang sangat bermanfaat dan menjadi salah satu tumpuan harapan manusia dalam meningkatkan kualitas hidup dan kesehatan. Kandungan bahan aktif pada tanaman Centella Asiatica seperti asam bebas, mineral, vitamin B dan C. Bahan utama yang dikandungnya adalah steroid yaitu triterpenoid glycoside. Kandungan triterpenoid saponin dalam pegagan berkisar $1-8 \%$. Unsur utama dalam triterpenoid saponin adalah asiatikosida dan madekassosida. Asiatikosida mampu bekerja sebagai detoksifikasi pada hati dan merupakan marker dalam penentuan standar bahan baku pada pegagan. ${ }^{9}$ Menurut Syifaiyah secara umum, pegagan berkhasiat sebagai hepatoprotektor yaitu melindungi sel hati dari berbagai kerusakan akibat racun dan zat berbahaya. ${ }^{10}$

\section{METODE}

Penelitian menggunakan rancangan true eksperimental dengan desain Post test Only Control Group Design. Penelitian dilakukan di Laboratorium Farmakologi Universitas Mataram dan pemeriksaan profil darah \& hepar di RS Kota Mataram. Sampel penelitian adalah tikus putih (Rattus novergicus) dengan jumlah 25, yang terdiri dari 5 kelompok (kelompok negatif, kelompok positif, kelompok intervensi $250 \mathrm{mg}$, intervensi 500mg, dan intervensi 1000mg).

Proses penelitian dimulai dengan aklimitasi tikus selama 1 minggu, kemudian dilanjutkan dengan pemberian ekstrak pegagan dan paparan asap rokok pada tiap kelompok selama 7 minggu. Data dianalisis menggunakan uji normalitas, ANOVA dan post hoc.

Penelitian dilakukan setelah mendapat persetujuan dari Komisi Etik Penelitian Kesehatan Universitas Mataram Nomor: 213/UN18.F7/ETIK/2019.

\section{HASIL}

Rerata dari pengukuran limfosit pada kelima kelompok perlakuan, diketahui bahwa pemberian ekstrak pegagan dengan dosis yang berbeda mempengaruhi nilai rerata limfosit. Rerata tertinggi pada kelompok 2 sebesar $(69,18 \pm 4,61) 10^{3} / \mu \mathrm{L}$. Rerata terendah pada kelompok 5 sebesar $(39,22 \pm 36,39)$ $10^{3} / \mu \mathrm{L}$ dapat dilihat pada Gambar 1 . 


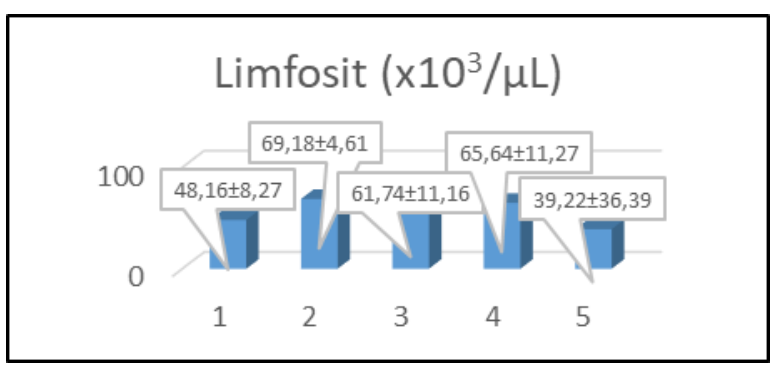

Gambar 1. Rerata nilai limfosit

Rerata pengukuran trombosit pada kelima kelompok perlakuan, diketahui bahwa pemberian ekstrak pegagan dengan dosis yang berbeda mempengaruhi nilai rerata trombosit. Rerata trombosit tertinggi pada kelompok 2 sebesar $(1120,60 \pm 135,28)$ $10^{3} / \mu \mathrm{L}$, sedangkan rerata terendah pada kelompok 5 sebesar $(589,40 \pm 540,49) 10^{3} / \mu \mathrm{L}$ (Gambar 2).

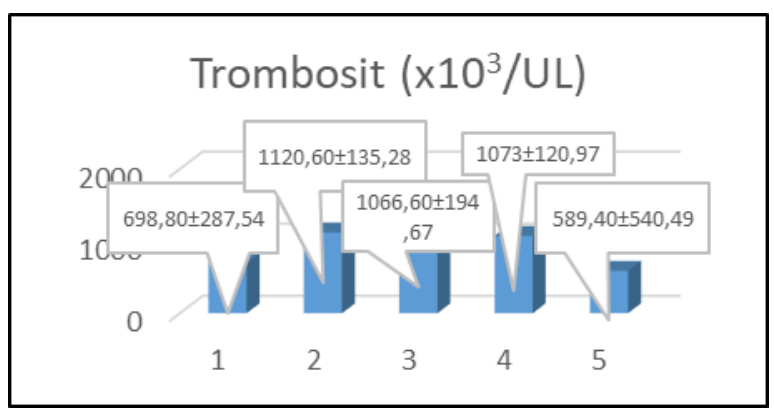

Gambar 2. Rerata nilai trombosit

Hasil uji ANOVA menunjukkan profil darah (leukosit, neutrofil, monosit, eosinofil, eritrosit, dan hemoglobin) dengan $p>0,05$, yang artinya tidak ada pengaruh ekstrak pegagan terhadap nilai profil darah pada tikus putih yang diinduksi asap rokok. Pada nilai limfosit dan trombosit $(p<0,05)$, yang artinya ada pengaruh ekstrak pegagan terhadap nilai limfost dan trombosit pada tikus putih yang diinduksi asap rokok. (Gambar 3).

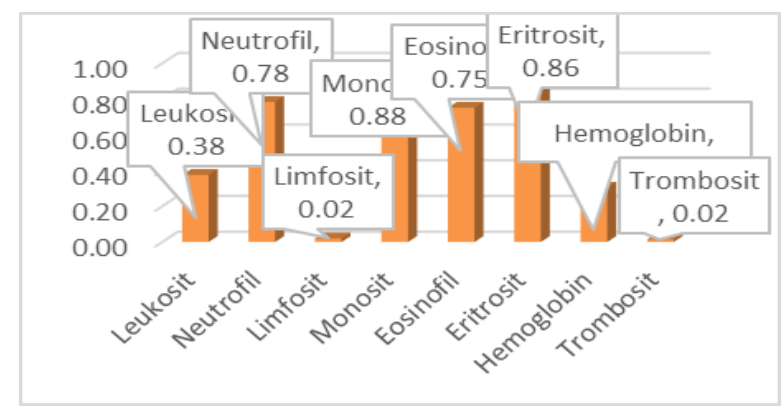

Gambar 3. Rerata nilai profil darah
Hasil uji ANOVA menunjukkan SGPT $(p=0,056)$ dan SGOT $(p=0,924)$, artinya $p>0,05$, yang artinya tidak ada pengaruh ekstrak pegagan terhadap profil darah pada tikus putih yang diinduksi asap rokok (Gambar 4).

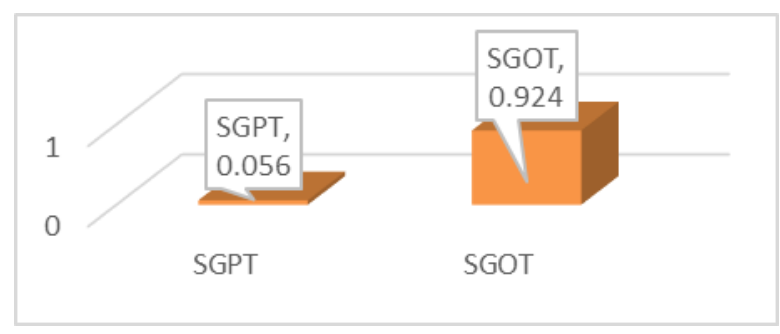

Gambar 4. Hasil uji Anova profil hepar

\section{PEMBAHASAN}

Perlakuan dilakukan dengan pemberian ekstrak pegagan pada 5 kelompok; kontrol negatif, kontrol positif, dosis pegagan $250 \mathrm{mg} / \mathrm{kgbb}$, dosis pegagan $500 \mathrm{mg} / \mathrm{kgbb}$, dosis pegagan $1000 \mathrm{mg} / \mathrm{kgbb}$. Berdasarkan hasil analisis statistik dengan ANOVA diperoleh hasil yang menunjukkan bahwa $p$ value > $(0,05)$ pada pemeriksaan leukosit, neutrofil, monosit, eosinofil, eritrosit, dan hemoglobin yang berarti $\mathrm{HO}$ diterima dan $\mathrm{H} 1$ ditolak. Pada nilai limfosit dan trombosit dengan $\mathrm{p}$ value $<(0,05)$, yang berarti $\mathrm{HO}$ ditolak dan $\mathrm{H} 1$ diterima. Hal ini menunjukkan ada pengaruh ekstrak pegagan terhadap profil darah (limfosit dan trombosit) pada kelima kelompok perlakuan.

Hasil uji ANOVA nilai limfosit menunjukkan nilai $\mathrm{p}=0,020<(0,05)$, hasil ini menandakan bahwa ada pengaruh ekstrak pegagan terhadap nilai limfosit pada tikus putih yang diinduksi asap rokok. Berdasarkan rerata dari pengukuran limfosit pada kelima kelompok perlakuan, diketahui bahwa pemberian ekstrak pegagan dengan dosis yang berbeda mempengaruhi nilai rerata limfosit. Rerata kadar limfosit pada kelompok 2 (kontrol positif) menunjukkan peningkatan $(69,18 \pm 4,61) 10^{3} / \mu \mathrm{L}$.

Uji Post Hoc Test memperlihatkan bahwa kelompok yang menunjukan adanya perbedaan rerata limfosit pada kelompok 1 dan 2. Jumlah limfosit pada kelompok yang diinduksi asap rokok meningkat dan nilainya berbeda signifikan dengan kelompok kontrol. Hal ini sejalan dengan hasil penelitian Paim et al 2012 
bahwa tikus yang diinduksi asap rokok dapat mengalami limfositosis, dan menunjukkan peranan limfosit dalam sistem tanggap kebal seluler. ${ }^{11}$

Hasil rerata dari pengukuran leukosit tertinggi pada kelompok 2 sebesar $(10,11 \pm 1,35) 10^{6} / \mu \mathrm{L}$. Asap rokok diketahui 20-25\% menyebabkan peningkatan jumlah leukosit di perifer (leukositosis). Adanya rekrutmen lokal leukosit ke permukaan sel endotel mengawali terjadinya aterosklerosis sebagai akibat meningkatnya resistensi pembuluh darah perifer oleh penghambatan sirkulasi ke pembuluh darah kecil. ${ }^{12}$

Rerata trombosit tertinggi pada kelompok 2 sebesar $(1120,60 \pm 135,28) 10^{3} / \mu \mathrm{L}$. Penelitian yang dilakukan oleh Blann et al menunjukkan hasil antara merokok dengan kadar trombosit pada perokok didapatkan peningkatan bermakna parameter trombosit yang lain, yakni platelet surface P-selectin yang diduga lebih sensitif terhadap paparan asap rokok. ${ }^{13}$ Beberapa penelitian lain menunjukkan hasil hubungan merokok dengan kadar trombosit. Penelitian lain menunjukkan dilakukan oleh Nagvekar et al pada hewan coba tikus yang diberikan paparan asap rokok selama 12 minggu memberikan hasil peningkatan trombosit jika dibandingkan dengan kelompok tikus control. $^{14}$

Hasil uji Anova pada pemeriksaan profil hepar sdiperoleh nilai $\mathrm{p}>0,05$ yang artinya tidak ada perbedaan signifikan kadar SGPT dan SGOT pada kelima kelompok perlakuan. Pengukuran SGPT pada kelima kelompok perlakuan, nilai rerata tertinggi pada kelompok 4 sebesar $(55,00 \pm 8,51) \quad \mu / L$. Hal ini menunjukkan bahwa hati mengalami kerusakan, ini dikarenakan konsentrasi kadar SGPT terbanyak berada di jaringan hati. ${ }^{15}$

Hasil penelitian menunjukkan penurunan kadar SGPT pada kelompok 3 sebesar $(37,20 \pm 5,26) \mu / L$. Mekanisme penurunan kadar SGPT pada kelompok dengan pemberian ekstrak pegagan dengan dosis $500 \mathrm{mg} / \mathrm{kgbb}$. Kandungan senyawa flavanoid dari ekstrak pegagan dapat berpengaruh dalam menghambat kerusakan hati dengan cara mengikat radikal bebas sehingga dampaknya terhadap hati berkurang. Senyawa flavonoid dapat menghambat banyak reaksi oksidasi. Flavonoid bertindak sebagai penampung yang baik bagi radikal hidroksi dan superoksida serta melindungi membran lipid terhadap reaksi yang merusak. Aktivitas antioksidannya dapat digunakan secara tradisional untuk mengobati gangguan fungsi hati. ${ }^{17}$

Penelitian yang dilakukan oleh Anthony et al, membuktikan bahwa asiatikosida sebagai kandungan utama dari triterpenoid dapat meningkatkan efek antioksidan sehingga mampu melindungi kerusakan hepar akibat hepatotoksin ${ }^{18}$. Madekasosida dan asam madekasat membantu penyembuhan kerusakan hepar karena aktivitas antiinflamatori dan imunomodulator yang dimilikinya. ${ }^{19}$ total glukosida dari pegagan turut memperbaiki fungsi hepar yang rusak $^{20}$. Dengan demikian jika sel-sel hati telah mampu meregenerasi diri kembali, maka kadar enzim GPT maupun GOT dapat dipertahankan untuk tetap berada pada keadaan normal sehingga tidak menyebabkan tingginya kadar SGPT dan SGOT ${ }^{10}$.

\section{SIMPULAN}

Pemeriksaan profil darah pada tikus putih yang diinduksi asap rokok hanya nilai limfosit dan trombosit yang terdapat perbedaan tiap kelompok, sedangkan untuk lainnya tidak menunjukkan perbedaan tiap kelompok.

Pemeriksaan profil hepar pada tikus putih yang diinduksi asap rokok tidak menunjukkan perbedaan tiap kelompok.

\section{SARAN}

- Mencari dosis yang paling efektif untuk menimbulkan efek hepatoprotektif, misalnya dengan interval dosis yang lebih sempit dan berkisar antara 10mg $-50 \mathrm{mg}$ dosis ekstrak pegagan

- Menggunakan alat smoking pump yang standar.

- Melakukan ekstraksi dengan pelarut lain yang lebih sesuai misalnya dengan menggunakan air saja.

- Memperpanjang waktu perlakuan.

\section{DAFTAR PUSTAKA}

1. Canadian Center For Occupational Health \& Safety (CCOHS). Environmental Tobacco Smoke (ETS): General Information and Health Effects. Februari 2017 (diakses 2020). Tersedia dari: https://www.ccohs.ca/ oshanswers/psychosocial/ ets health.htm 
2. Rufaridah, A. Pengaruh perokok pasif terhadap plasenta, berat badan lahir, apgar score bayi baru lahir pada ibu hamil di Kabupaten Padang Pariaman Tahun 2011 (tesis). Padang: Prodi IImu Bomedik, Fakultas Kedokteran, Universitas Andalas; 2012.

3. Carel RS, Eviatar J. Factors affecting leukocyte count in healthy adults. Prev Med (Baltim). 1985;14(5):607-19.

4. Asif M, Karim S, Umar Z, Malik A, Ismail T, Chaudhary $A$, et al. Effect of cigarette smoking based on hematological parameters: Comparison between male smokers and nonsmokers. Turkish J Biochem. 2013; 38(1):75-80.

5. Islam MM, Amin MR, Begum S, Akther D, Rahman A. total count of white blood cells in adult male smokers. J Bangladesh Soc Physiol. 1970;2:49-53.

6. Butkiewicz AM, Kemona-Chetnik I, DymickaPiekarska V, Matowicka-Karna J, Kemona H, Radziwon P. Does smoking affect thrombocytopoiesis and platelet activation in women and men? Adv Med Sci. 2006;51:123-6.

7. Ihedioha JI, Ugwuja JI, Noel-Uneke OA, Udeani IJ, Daniel-Igwe G. Reference values for the haematology profile of conventional grade outbred albino mice (Mus musculus) in Nsukka, Eastern Nigeria. Anim Res Int. 2012;9(2):160112 .

8. Besung. Pegagan (Centella Asiatica) sebagai alternatif pencegahan penyakit infeksi pada ternak. Buletin Veteriner Udayana.2012;7:201

9. Selfitri AD. Efek elisitasi dan transformasi genetik terhadap produksi asiatikosida pada kalus pegagan (centella asiatica (I.) Urban). [skripsi]. Bandung: Institut Teknologi Bandung; 2009.

10. Syifaiyah B. Pengaruh pemberian ekstrak daun pegagan (Centela asiatica) terhadap kadar SGPT Dan SGOT hati mencit (Mus Musculus) yang diinduksi dengan parasetamol [skripsi]. Malang:
Fakultas Sains Dan Teknologi, Universitas Islam Negeri Malang; 2008.

11. Paim CB, Paim FC, Da Silva AS, Franca RT. Thrombocytopenia and platelet activity in dogs experimentally infected with Rangelia vitalii. Veterinary Parasitology. 2011;185(2-4):131-7

12. Nighute $S$, Khatoon $M$, Awari $A$, Ishaque $M$. The influence of aging on auditory evoked potential in advanced age group. International Journal of Biomedical Research. 2012;3(11):422-6.

13. Blann AD, Kirkpatrick U, Devine $C$, Naser $S$, McCollum CN. The influence of acute smoking on leucocytes, platelets and the endothelium. Atherosclerosis. 1998 Nov; 141 (1):133-9.

14. Nagvekar M AM. Effect of Alone, cigarette smoking and $3.2 \%$ ethanol In, or together on RBC and platelet counts in rats. Ind J Physiol Pharmacol. 2002;46:367.

15. Sadikin M. Biokimia Darah. Jakarta: Widya Medika; 2002.

16. Arief S. Radikal bebas [artikel ilmiah]. Surabaya: Bagian IImu Kesehatan Anak, Fakultas kedokteran, Universitas Airlangga; 2010.

17. Robinson T. Kandungan organik tumbuhan tinggi. Padmawinata K, penterjemah. Bandung: Institut Teknologi Bandung; 1995

18. Anthony B, Santhakumari G, Merina B, Sheeba V, Mukkadan J. Hepatoprotective effect of Centella asiatica (L) in carbon tetrachlorideinduced liver injury in rats. Indian J Pharm Sci, 2006, 68 (6): 772-6

19. Vohra K, Pal G, Gupta VK, Singh S, Bansal Y. An insight on Centella Asiatica Linn.: A review on recent research. Pharmacologyonline. 2011;2: 440-62.

20. Ming $Z$ jun, Liu $S$ zeng, Cao L. Effect of total glucosides of Centella asiatica on antagonizing liver fibrosis induced by dimethylnitrosamine in rats. Chinese Journal of Integrated Traditional and Western Medicine. 2004 Aug;24(8):731-4 